\title{
Habitat or matrix: which is more relevant to predict road-kill of vertebrates?
}

\author{
C. Bueno ${ }^{a}$, C. O. M. Sousa $a^{b}$ and S. R. Freitas ${ }^{c *}$ \\ aUniversidade Veiga de Almeida - UVA, Rua Ibituruna, 108, CEP 20271-901, Rio de Janeiro, RJ, Brazil \\ ${ }^{\text {b}}$ Departamento de Ecologia, Instituto de Biociências, Universidade de São Paulo - USP, Rua do Matão, 321, Travessa 14, \\ CEP 05508-900, São Paulo, SP, Brazil \\ ${ }^{\circ}$ Centro de Ciências Naturais e Humanas - CCNH, Universidade Federal do ABC - UFABC, Avenida dos Estados, 5001, \\ Bloco A, Sala 631-3, CEP 09210-170, Santo André, SP, Brazil \\ *e-mail: simonerfreitas.ufabc@gmail.com
}

Received: July 14, 2014 - Accepted: September 7, 2014 - Distributed: November 30, 2015

(With 1 figure)

\begin{abstract}
We believe that in tropics we need a community approach to evaluate road impacts on wildlife, and thus, suggest mitigation measures for groups of species instead a focal-species approach. Understanding which landscape characteristics indicate road-kill events may also provide models that can be applied in other regions. We intend to evaluate if habitat or matrix is more relevant to predict road-kill events for a group of species. Our hypothesis is: more permeable matrix is the most relevant factor to explain road-kill events. To test this hypothesis, we chose vertebrates as the studied assemblage and a highway crossing in an Atlantic Forest region in southeastern Brazil as the study site. Logistic regression models were designed using presence/absence of road-kill events as dependent variables and landscape characteristics as independent variables, which were selected by Akaike's Information Criterion. We considered a set of candidate models containing four types of simple regression models: Habitat effect model; Matrix types effect models; Highway effect model; and, Reference models (intercept and buffer distance). Almost three hundred road-kills and 70 species were recorded. River proximity and herbaceous vegetation cover, both matrix effect models, were associated to most road-killed vertebrate groups. Matrix was more relevant than habitat to predict road-kill of vertebrates. The association between river proximity and road-kill indicates that rivers may be a preferential route for most species. We discuss multi-species mitigation measures and implications to movement ecology and conservation strategies.
\end{abstract}

Keywords: connectivity, conservation, landscape ecology, rivers, road ecology.

\section{Habitat ou matriz: qual é mais relevante para prever atropelamentos de vertebrados?}

\begin{abstract}
Resumo
Nós acreditamos que nos trópicos, precisamos de uma abordagem de comunidade para avaliar os impactos das estradas sobre a vida silvestre, e então, sugerir medidas de mitigação para grupos de espécies ao invés da abordagem de espécie-foco. Compreender quais características da paisagem indicam eventos de atropelamento podem também fornecer modelos que podem ser aplicados em outras regiões. Nós pretendemos avaliar se habitat ou matriz é mais relevante para prever eventos de atropelamento para grupos de espécies. Nossa hipótese é: matriz mais permeável é o fator mais relevante para explicar os eventos de atropelamentos. Para testar essa hipótese, escolhemos vertebrados como a assembléia estudada e uma rodovia cruzando uma região de Mata Atlântica no sudeste do Brasil como área de estudo. Modelos de regressão logística foram criados usando presença/ausência de eventos de atropelamentos como variáveis dependentes e características da paisagem como variáveis independentes, os quais foram selecionados pelo Critério de Informação de Akaike. Nós consideramos um conjunto de modelos candidatos contendo quatro tipos de modelos de regressão simples: modelo de efeito de habitat; modelos de efeito de tipos de matriz; modelo de efeito da rodovia; e, modelos de referência (intercepto e distância da faixa de influência). Quase 300 atropelamentos e 70 espécies foram registradas. Proximidade do rio e cobertura da vegetação herbácea, ambos modelos de efeito da matriz, foram associadas à maioria dos grupos de vertebrados atropelados. Matriz foi mais relevante do que habitat para prever atropelamentos de vertebrados. A associação entre proximidade do rio e atropelamentos indica que rios podem ser a rota preferencial para a maioria das espécies. Nós discutimos medidas de mitigação multi-espécies e implicações para a ecologia do movimento e estratégias de conservação.
\end{abstract}

Palavras-chave: conectividade, conservação, ecologia de paisagens, rios, ecologia de estradas. 


\section{Introduction}

Collisions between vehicles and vertebrates have been studied in temperate countries for many decades (Forman et al., 2003; Van der Ree et al., 2011). In South America, studies on the impacts of roads have been developed only recently and there are few studies published in the last 10 years, mostly in Brazil (Dornas et al., 2012). In general, the road-kill vertebrate community in tropics is more diverse and small-sized than from temperate region; therefore the consequences of the collisions may be different, especially regarding security issues (Dornas et al., 2012; Huijser et al. 2009). In North Hemisfere countries, collisions with large-sized mammals often cause serious accidents, including loss of human lives or substantial material damages for the driver (Huijser et al., 2009; Seiler, 2005). On the other hand, there is less large-sized wildlife hit by vehicles in tropics than small ones and thus the damages and human losses should be lower. However, the diversity of species killed in collisions with vehicles is higher in tropics, and thus the conservation issues may become more relevant than security ones, especially in protected areas (Dornas et al., 2012; Garriga et al., 2012).

In Brazil, there are estimates of $8.65( \pm 26.37)$ vertebrate road-kill/km/year, representing $14.7( \pm 44.8)$ million road-kill/year throughout Brazil's territory (Dornas et al., 2012). Some vertebrate species are usually more hit by vehicles in Brazil, such as, the crab-eating fox (Cerdocyon thous Linnaeus, 1766) and the capybara (Hydrochoerus hydrochaeris Linnaeus, 1766; Dornas et al., 2012). In roads of an Atlantic Forest-Cerrado interface, Cáceres (2011) showed that abundance was the more important variable influencing mammal road-kill, followed by habit (mostly nocturnal). Some of the largest road-killed mammals are the maned wolf (Chrysocyon brachyurus Illiger, 1815) and the jaguar (Panthera onca Linnaeus, 1758; Dornas et al., 2012), which are included in the IUCN red list of threatened species (IUCN, 2013). The high species diversity usually found dead on roads in tropics is also a conservation concern, especially when threatened species are included. Most species have few road-kill records and thus may not represent a significant mortality rate in the population level. However, for rare species, some deaths on the road in a fragmented landscape may represent a threat of local extinction, indicating a conservation concern and the relevance of the community approach (Laurance et al., 2009).

Roads may affect wildlife populations through barrier effects, leading to reduction of local genetic diversity and isolating populations (Balkenhol and Waits, 2009; Lesbarrères et al., 2006). Wildlife crossings are one of the measures used to mitigate barrier effects and reduce wildlife road-kill, improving connectivity between habitats fragmented by roads (Beckmann et al., 2010; Corlatti et al., 2009; Lesbarrères and Fahrig, 2012). These crossings should not lead to ecological "dead-ends", but must link to a larger functional landscape and habitat complex that allows wildlife to disperse, move freely, and meet their daily and life needs now and in the future, including projected land-use changes (Beckmann et al., 2010). Maps, road-kill data and GIS tools are useful to identify where to locate wildlife crossings and other types of mitigation (Beckmann et al., 2010; Clevenger et al., 2003). Road-kill data alone is not enough to estimate wildlife movement areas and should be combined with habitat linkage mapping to improve this evaluation in order to choose the places where mitigation measures should be built (Beckmann et al., 2010; Clevenger et al., 2003). Usually, considerations of wildlife crossing placement begin by determining the focal species or group (Beckmann et al., 2010; Gunson et al., 2011). There are some differences in tropical landscapes that raise the need of some methodology changes to identify the crossings placement. In a high species richness and low abundance condition, it is necessary a community level approach gathering many species with different behavior and dispersal capacity. In tropics, land use and land cover changes in decades representing habitat loss and expansion of crops, pasture or urban areas (Dobrovolski et al., 2011; Freitas et al., 2010; Soares-Filho et al., 2004) and then, there is a risk of building a wildlife crossing where in a near future could be an ecological "dead-end". Considering landscape dynamics, understand which landscape characteristics indicate road-kill events may also provide models that can be applied in other regions and adaptable to changes because the mitigation measure would be associated to a landscape feature instead to road-kill aggregations. In addition, some landscape characteristics are relevant to understand animal movements, preferential routes and matrix permeability for species (Prevedello and Vieira, 2010). Is expected that species, as possible, move in a straight line, for instance along river margins, because represent "low energy" paths, particularly in mountain areas, where, in contrast, steep slopes represent "high energy" paths (Shepard et al., 2013). Thus, rivers and water bodies, due to movement behavior and resource use (Zeller et al., 2012) may be important landscape characteristics to predict preferred crossing sites and the best location where apply mitigation measures (Schuster et al., 2013).

In this context, landscape approach could be a way to evaluate road-kill pattern and to indicate sites to apply mitigation measures, and even provide predictive models that can be applied in other regions. The relationship between road-kill events and landscape characteristics may be studied using many species, and thus, promoting a community approach. As road-killed animals are, before collision with vehicle, moving through matrix types, landscape approach would be used to understand how these species use matrix and which matrix types are more permeable for a group of species. We intend to evaluate if habitat or matrix is more relevant to predict road-kill events for a group of species. Our hypothesis is: more permeable matrix is the most relevant variable to explain road-kill events. To test this hypothesis, we chose vertebrates as the studied assemblage and a highway crossing in an Atlantic Forest region in southeastern Brazil as the study site. 


\section{Material and Methods}

\subsection{Study area}

The study was carried out in highway BR-040, in the $180.4 \mathrm{~km}$ section from $\mathrm{km} 125.2$ in Rio de Janeiro State $\left(22^{\circ} 48^{\prime} 02^{\prime \prime} \mathrm{S}\right.$ and $\left.43^{\circ} 17^{\prime} 26^{\prime \prime} \mathrm{W}\right)$ to $\mathrm{km} 773.5$ in Minas Gerais State (21 $38^{\prime} 34^{\prime \prime} \mathrm{S}$ and $\left.43^{\circ} 26^{\prime} 10^{\prime \prime} \mathrm{W}\right)$, southeastern Brazil (Figure 1). The surveyed section crosses nine municipalities: six in the state of Rio de Janeiro (Rio de
Janeiro, Duque de Caxias, Petrópolis, Areal, Três Rios and Comendador Levy Gasparian), and three in Minas Gerais state (Simão Pereira, Matias Barbosa and Juiz de Fora). The topography varies from the lowlands near Duque de Caxias city (19 m high, $22^{\circ} 47^{\prime} 09^{\prime}$ ' S, 43 $\left.3^{\circ} 18^{\prime} 43^{\prime \prime} \mathrm{W}\right)$, through the mountain range (about 1,000 $\mathrm{m}$ high) and Petrópolis city (838 m high, $\left.22^{\circ} 30^{\prime} 18^{\prime \prime} \mathrm{S}, 43^{\circ} 10^{\prime} 44^{\prime \prime} \mathrm{W}\right)$ up to Juiz de Fora city ( $715 \mathrm{~m}$ high, $21^{\circ} 41^{\prime} 20^{\prime}$ ' S, 43 $20^{\circ} 40^{\prime \prime} \mathrm{W}$ ). Within this entire range, the road has paved 2-lane in

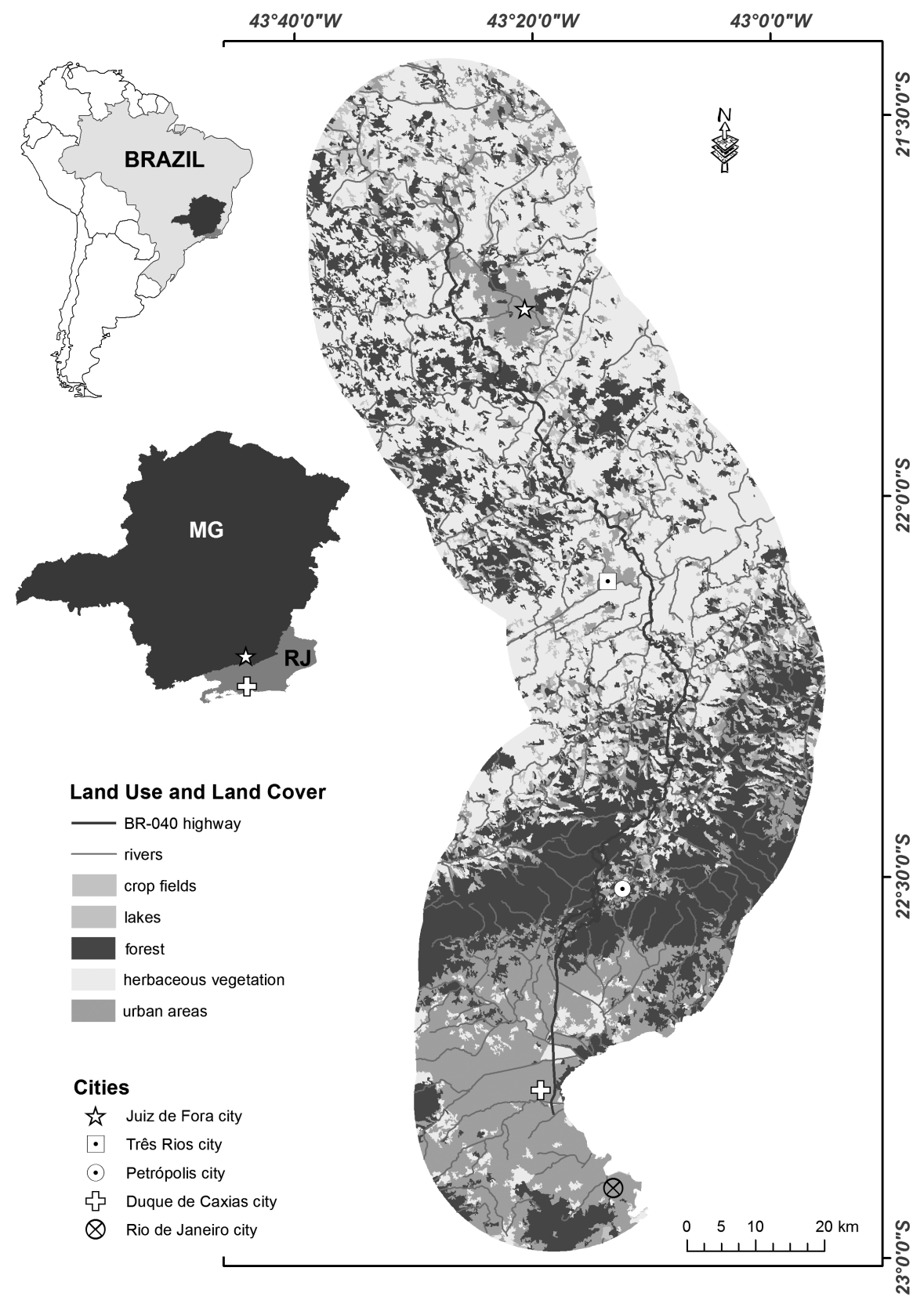

Figure 1. Study area: BR-040 highway from the km 125.1, near Duque de Caxias city in Rio de Janeiro State (RJ) to the $\mathrm{km}$ 773.5, near Juiz de Fora city in Minas Gerais State (MG), Southeastern Brazil. Landscape characteristics 20-km around BR-040 highway are shown in detail. The Guanabara Bay is located in southeast of the map, where 20-km buffer is cut, near Duque de Caxias city, but it was not considered as landscape characteristics. 
each direction and for the stretch crossing the mountain range, the 2-lane going up and the 2-lane going down run separately. Thus, the road is divided in 2-lane going up and 2-lane going down from km 102 at Duque de Caxias municipality up to $\mathrm{km} 72$ at Petrópolis municipality, where it crosses the Biodiversity Corridor of Serra do Mar (the larger dark green patch, near Petrópolis city, in Figure 1). In addition, from $\mathrm{km} 125.2$ to $\mathrm{km} 102$ in Rio de Janeiro State, the road has 2-lane in each direction. Similarly, the last stretch from $\mathrm{km} 72$ to $\mathrm{km} 0$ (in Rio de Janeiro State) and $\mathrm{km} 828.7$ to $\mathrm{km} 773.5$ (in Minas Gerais State) also has 2-lane in each direction.

Most adjacent landscape of BR-040 is composed by herbaceous cover (pasture and grasslands, 42.7\%), followed by forest cover (29.9\%) and urban areas $(21.6 \%$, Figure 1). The larger tropical rain forest remnant constitutes the Biodiversity Corridor of Serra do Mar (Figure 1), encompassing two natural reserves: Petrópolis Protected Area ("Área de Proteção Ambiental de Petrópolis") and Tinguá Biological Reserve ("Reserva Biológica do Tinguá").

The BR-040 stretch between Petrópolis and Juiz de Fora was constructed in 1861 by Brazil's Emperor Dom Pedro II (Lima Neto, 2001). The stretch between the cities of Petrópolis and Rio de Janeiro was constructed in 1928 by President Washington Luís, and in 1931, it was the first paved road in Brazil. Since 1996, the BR-040 stretch from Rio de Janeiro to Juiz de Fora has been under the authority of a private company, Concer. The mean traffic volume on the BR-040 is more than 39,046 vehicles/day (Petrópolis, 2010).

\subsection{Data collection}

We recorded wildlife killed on the road daily for 3 years (from April 2006 to April 2009), along $180.4 \mathrm{~km}$ on BR-040 between the cities of Rio de Janeiro and Juiz de Fora (Figure 1). We do not analyzed temporal variation in this study and decided to aggregate all 3 years data because of sample size matters. After training given by Cecilia Bueno, Concer workers collected road-kill animals found on the highway for 24 hours a day, 7 days a week, with an estimated average speed of $50 \mathrm{~km} / \mathrm{h}$. The advantage of the data collecting work in collaboration to Concer was the monitoring for 24 hours a day, 7 days a week. We expect this high monitoring rate could minimize the effect of carcass removal rates by vultures on road-kill records (Teixeira et al., 2013). In addition to monitoring by Concer employees, Cecilia Bueno has monitored the highway monthly up to August 2007 and each two weeks after that. When road-kill vertebrate was found on the road, it was recorded in a form that included date, time and site $(\mathrm{km})$ of record, common name of animal, road lane and direction, weather (e.g. rainy), animal's condition (dead, hurt, alive) and name of Concer worker. Photographs of each killed animal and landscape in the surroundings were taken. For alive or hurt animals, the procedure was release it or rescue to vet treatment afterwards. About 9\% of the animals were found alive on the highway. For dead animals, the procedures were taxidermy, fixation on alcohol
$70 \%$ or discard after taxonomic identification. The dead animals to be taxidermized were kept in freezers located on Concer office on BR-040, and after taken to laboratory for taxidermy. The taxidermized carcasses were deposited on National Museum of Rio de Janeiro collection. In this work, we analyzed only animals found dead and with taxonomic identification.

\subsection{Data analysis}

A map of land use and land cover of the studied area was made by means of Landsat images of 2002, with a $1: 250,000$ scale and accuracy of $86.39 \%$ (IESB, 2007). Considering the scale used, the landscape did not change significantly in a decade, thus the landscape map represents well the time when road-kill data was collected. The area $25 \mathrm{~km}$ around the BR-040 was used to landscape analysis (Figure 1). The landscape characteristics around each road-kill were quantified using vector data: forest cover, herbaceous cover, crop fields, and urban area. In order to evaluate the effect of scale on models (Schuster et al., 2013), we used three distances from road-kill to measure landscape characteristics at $1 \mathrm{~km}, 5 \mathrm{~km}$ and $10 \mathrm{~km}$. We measured the highway density in a $1 \mathrm{~km}$ buffer to represent curved and straight section along the BR-040. The distance of road-kill to the nearest river was also measured. We sorted out the same number of road-kill along the highway to represent absences in logistic regression models. The same landscape characteristics were measured up to $1 \mathrm{~km}, 5 \mathrm{~km}$ and $10 \mathrm{~km}$ from each absence point. All landscape measures were done using ArcGIS version 9.3.1. Logistic regression models were generated using presence/absence of road-kill as dependent variables and landscape characteristics as independent variables. For the presence/absence of road-kill, we considered a set of candidate models containing four types of simple regression models: 1) Habitat effect model $(\mathrm{H})$ including forest cover $(\mathrm{H} 1)$, because in Atlantic Forest the predominant habitat is tropical forest; 2) Matrix types effect models (M), including distance of the nearest river (M1), herbaceous vegetation cover (M2), crop fields (M3) and urban area (M4); 3) Highway effect model (H), including road density (H1); and two Reference models (R), which did not contain the other effects, but only the intercept (R0) or the variable considering buffer distance $\left(\mathrm{R}_{\mathrm{b}}\right)$. Models were run using Generalized Linear Models (GLM) in R 2.11.0, and model selection was based on the Akaike's Information Criterion (Burnham and Anderson, 2002) with correction for small samples (AICc). To sort the best models and evaluate their performance, we used the AIC weight (wi) and evidence (wi_max / wi_i; Burnham and Anderson, 2002).

The logistic regression analysis, followed by model selection, was done for all species together and for the following sub-groups: mammals, large mammals, arboreal or volant mammals, reptiles, all birds, and owls (Table 1). The selection of sub-groups was based on body size, locomotion type and taxonomic category (Table 1). The road-kill records limited the division of sub-groups, such as, arboreal and volant mammals. Particularly this 
Table 1. Road kill records of vertebrate species during three years on BR-040. The species are separated by sub-groups used in regression analysis.

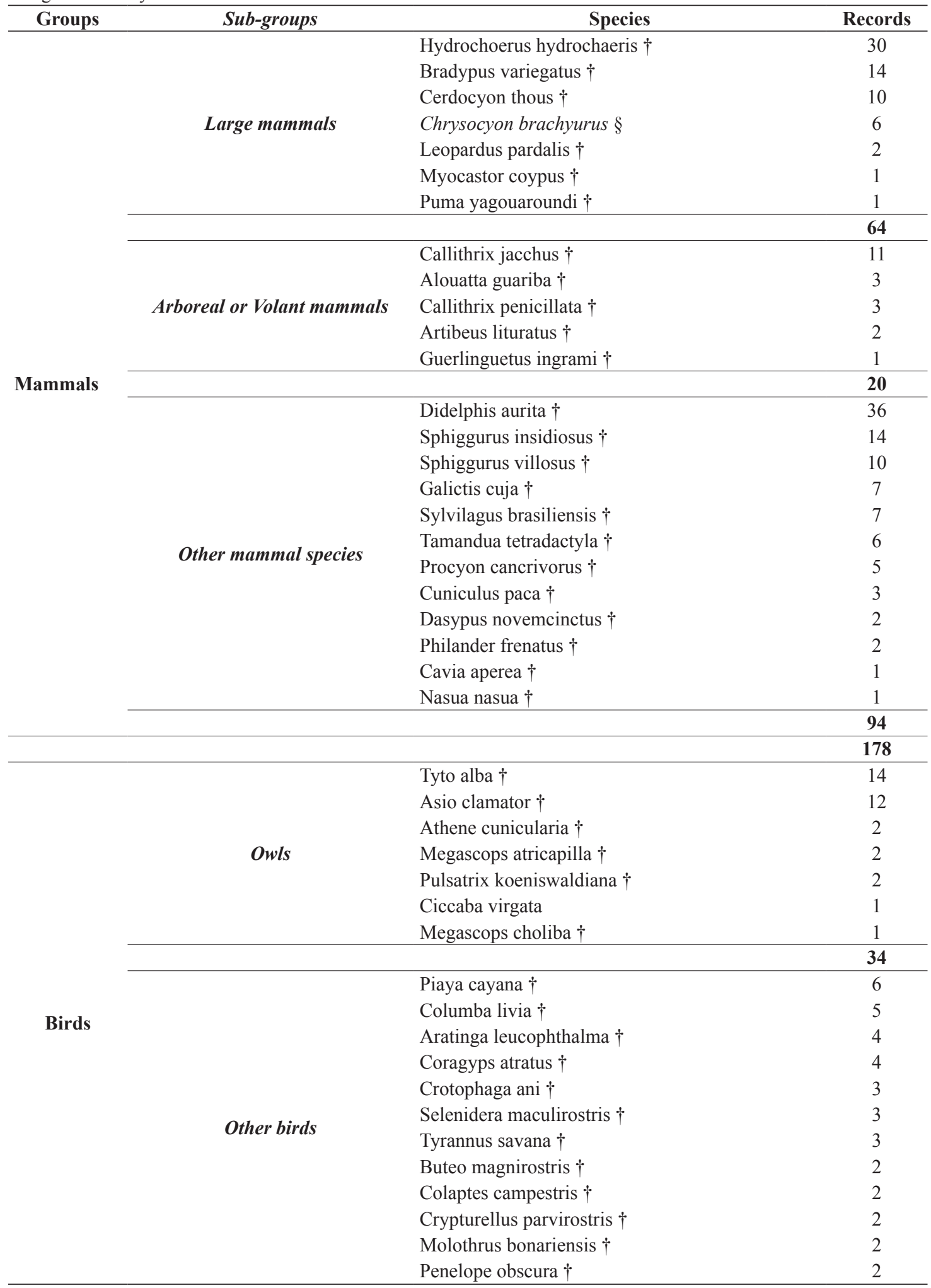

Species under extinction risk are indicated by symbols († Least Concern, $\$$ Lower Risk/Least Concern, $\S$ Near Threatened), and no symbol means that the taxon has not yet been assessed for the IUCN Red List (IUCN, 2013). The identification and classification in sub-groups was based on Reis et al. (2010) and scientific names on Roskov et al. (2013). 
Table 1. Continued...

\begin{tabular}{|c|c|c|c|}
\hline Groups & Sub-groups & Species & Records \\
\hline \multirow{20}{*}{ Birds } & \multirow{20}{*}{ Other birds } & Streptoprocne zonaris $\uparrow$ & 2 \\
\hline & & Turdus rufiventris $\dagger$ & 2 \\
\hline & & Aramides saracura $\dagger$ & 1 \\
\hline & & Baryphthengus ruficapillus $\dagger$ & 1 \\
\hline & & Cariama cristata $\dagger$ & 1 \\
\hline & & Colaptes melanochloros $\dagger$ & 1 \\
\hline & & Columbina talpacoti $\uparrow$ & 1 \\
\hline & & Gallinula chloropus $\dagger$ & 1 \\
\hline & & Leptotila rufaxilla $\dagger$ & 1 \\
\hline & & Micrastur ruficollis $\dagger$ & 1 \\
\hline & & Milvago chimachima $\uparrow$ & 1 \\
\hline & & Nyctidromus albicollis $\dagger$ & 1 \\
\hline & & Caracara plancus $\dagger$ & 1 \\
\hline & & Ramphastos vitellinus $\dagger$ & 1 \\
\hline & & Rupornis magnirostris & 1 \\
\hline & & Tangara cayana $\dagger$ & 1 \\
\hline & & Tersina viridis $\dagger$ & 1 \\
\hline & & Tyrannus melancholicus $\dagger$ & 1 \\
\hline & & & 58 \\
\hline & & & 92 \\
\hline \multirow{13}{*}{ Reptiles } & Crocodiles & Caiman latirostris $\ddagger$ & 2 \\
\hline & & & 2 \\
\hline & Lizards & Tupinambis merianae $\uparrow$ & 10 \\
\hline & & & 10 \\
\hline & \multirow{9}{*}{ Snakes } & Oxyrhopus clathratus & 5 \\
\hline & & Bothrops jararacussu $\uparrow$ & 3 \\
\hline & & Erythrolamprus aesculapii venustissimus & 2 \\
\hline & & Spilotes pullatus & 2 \\
\hline & & Bothrops jararaca & 1 \\
\hline & & Crotalus durissus $\uparrow$ & 1 \\
\hline & & Chironius bicarinatus & 1 \\
\hline & & & 15 \\
\hline & & & 27 \\
\hline Total & & & 297 \\
\hline
\end{tabular}

Species under extinction risk are indicated by symbols ( $†$ Least Concern, $\ddagger$ Lower Risk/Least Concern, $\S$ Near Threatened), and no symbol means that the taxon has not yet been assessed for the IUCN Red List (IUCN, 2013). The identification and classification in sub-groups was based on Reis et al. (2010) and scientific names on Roskov et al. (2013).

sub-group should represent mammals that probably cross over the road. These sub-groups were used as a way to cluster species with similar characteristics, such as body size, locomotion type and taxonomic category, providing a community level approach to indicate mitigation measures for many species as an attempt to fulfill some advances in Road Ecology research (Van der Ree et al., 2011).

\section{Results}

We recorded 279 road-kill vertebrates during the three-year study on the BR-040 highway, representing 0.52 road-kill $/ \mathrm{km} /$ year (Table 1 ). Most of them were mammals $(60 \%)$, followed by birds $(31 \%)$ and reptiles (9\%; Table 1). There were 70 species recorded, most of them birds ( 37 species, 53\%), followed by mammals $(24,34 \%)$ and reptiles $(9,13 \%$; Table 1$)$. The most road-killed species were the opossum Didelphis aurita (36 individuals), the capybara Hydrochoerus hydrochaeris (30), the sloth Bradypus variegatus (14), the porcupine Sphiggurus insidiosus (14), and the owls Tyto alba (14) and Asio clamator (12; Table 1). Only the maned wolf Chrysocyon brachyurus is considered Near Threatened and $87 \%$ of species recorded are classified as Least Concern by The IUCN Red List of Threatened Species (Table 1; IUCN, 2013).

Forest cover was significant, negative and highly correlated to herbaceous vegetation cover $(\mathrm{R}=-0.882$, $\mathrm{p}<0.01$ ), indicating the deforestation process for pasture 
Table 2. Regression models selected by AICc (Evidence $\leq 2)$ to explain road-kill of each species sub-group. Results of reference model (M0) is also showed through its independent variable (intercept).

\begin{tabular}{|c|c|c|c|c|c|c|c|c|}
\hline $\begin{array}{c}\text { Dependent } \\
\text { Variables }\end{array}$ & $\begin{array}{c}\text { Model } \\
\text { Code } \\
\end{array}$ & $\begin{array}{c}\text { Independent } \\
\text { Variables } \\
\end{array}$ & $\mathbf{k}$ & $\mathbf{n}$ & $\mathrm{AICc}$ & $\triangle \mathrm{AIC}$ & wAIC & Evidence \\
\hline \multirow{2}{*}{ All species } & M1 & $\begin{array}{l}\text { - distance of the } \\
\text { nearest river }\end{array}$ & 1 & 1704 & 2318.3 & 0.0 & 0.997 & 1.0 \\
\hline & R0 & intercept & 1 & 1704 & 2364.2 & 45.9 & 0.000 & $9.3 \mathrm{E}+09$ \\
\hline \multirow[t]{2}{*}{ Mammals } & M1 & $\begin{array}{l}\text { - distance of the } \\
\text { nearest river }\end{array}$ & 1 & 975 & 1321.7 & 0.0 & 1.000 & 1.0 \\
\hline & R0 & intercept & 1 & 975 & 1353.6 & 31.9 & 0.000 & $8.5 \mathrm{E}+06$ \\
\hline \multirow{2}{*}{$\begin{array}{c}\text { Large } \\
\text { mammals }\end{array}$} & M2 & $\begin{array}{c}+ \text { herbaceous } \\
\text { vegetation cover }\end{array}$ & 1 & 306 & 300.1 & 0.0 & 1.000 & 1.0 \\
\hline & R0 & intercept & 1 & 306 & 426.2 & 126.2 & 0.000 & $2.5 \mathrm{E}+27$ \\
\hline \multirow{2}{*}{$\begin{array}{l}\text { Arboreal } \\
\text { or Volant } \\
\text { mammals }\end{array}$} & M2 & $\begin{array}{c}+ \text { herbaceous } \\
\text { vegetation cover }\end{array}$ & 1 & 114 & 113.9 & 0.0 & 0.997 & 1.0 \\
\hline & R0 & intercept & 1 & 114 & 160.1 & 46.2 & 0.000 & $1.1 \mathrm{E}+10$ \\
\hline \multirow[t]{2}{*}{ Reptiles } & M2 & $\begin{array}{c}+ \text { herbaceous } \\
\text { vegetation cover }\end{array}$ & 1 & 144 & 150.1 & 0.0 & 1.000 & 1.0 \\
\hline & R0 & intercept & 1 & 144 & 201.7 & 51.5 & 0.000 & $1.6 \mathrm{E}+11$ \\
\hline \multirow{3}{*}{ All birds } & R0 & intercept & 1 & 558 & 775.6 & 0.0 & 0.237 & 1.0 \\
\hline & H1 & - road density & 1 & 558 & 776.2 & 0.6 & 0.173 & 1.4 \\
\hline & M4 & - urban area & 1 & 558 & 776.9 & 1.3 & 0.124 & 1.9 \\
\hline \multirow[t]{2}{*}{ Owls } & M2 & $\begin{array}{c}+ \text { herbaceous } \\
\text { vegetation cover }\end{array}$ & 1 & 204 & 166.6 & 0.0 & 1.000 & 1.0 \\
\hline & R0 & intercept & 1 & 204 & 284.8 & 118.3 & 0.000 & $4.8 \mathrm{E}+25$ \\
\hline
\end{tabular}

Where: $\mathrm{k}=$ number of parameters; AICc $=$ Akaike Information Criterion for small samples; $\triangle \mathrm{AIC}=$ difference between the AICc of a given model and that of the best model; $w \mathrm{AICc}=$ Akaike weights (based on AIC corrected for small sample sizes).

activities in the region. Regarding logistic regression models, river proximity and herbaceous vegetation cover, both matrix effect models, were associated to the most road-killed vertebrate groups (Table 2). For all species together and for mammals separately, road-kill was associated with river proximity, whereas for large and arboreal mammals, reptiles and owls, road-kill were related to higher herbaceous vegetation cover (Table 2). The best models of almost all groups showed a better performance than the reference model R0 (intercept). The exception was the model to explain bird road-kill that the reference model showed the best performance, indicating that road-kill of birds did not show a clear relationship with landscape characteristics. For birds, other models were also considered relevant, the ones including: (1) less road density, and (2) less urban area (Table 2). Habitat effect model, forest cover, was not relevant for any group of species (Table 2). It is important to notice that the other reference model, buffer distance $\left(\mathrm{M}_{\mathrm{b}}\right)$, was not relevant to explain road-kill of any vertebrate group, which indicates that scale of analysis was not relevant in our study.

\section{Discussion}

Matrix types effect models were more relevant than habitat effect model (forest cover) to predict road-kill of vertebrates. Two matrix types, river proximity and herbaceous vegetation cover, were associated to road-kill of most of vertebrate groups, indicating these are more permeable matrix types, which have implications on movement behavior of these species. More permeable matrix types improve functional connectivity in the landscape, representing more gene flow, less extinction risk and thus, a good conservation strategy under population and community perspectives (Taylor et al., 1993). The association between river proximity and road-kill of all species together and of mammals indicates that rivers may be a preferential route for them, minimizing energy costs (Shepard et al., 2013). In a mountain, rivers located in valleys represent food and water source, and also an easier way to move along them in forests. Elongated stream passages seem to be a more effective mitigation measure for multi-species approach (Lesbarrères and Fahrig, 2012), and thus could be a solution to improve connectivity and reduce road-kill in mountain tropical forests, where the preferential route seem to be along river margins. Forest cover, the habitat effect model, was not related to road-kill, although forest is habitat for most recorded species. Probably, river work as an attractor to individuals crossing the highway, and thus forest cover become less relevant to explain road-kill.

The positive relationship of large and arboreal mammals, owls and reptiles with herbaceous vegetation cover (matrix type) could be due to its use as habitat for some groups and as matrix for others. Grasslands and open herbaceous vegetation are habitat for some species of large mammals, such as maned wolf (Chrysocyon brachyurus, Coelho et al., 
2008) and capybara (Hydrochoerus hydrochaeris, Verdade and Ferraz, 2006). However, for arboreal mammals, forest is the habitat and herbaceous vegetation is a matrix, and thus forest patches may be more or less isolated for these species depending on how they use each matrix type (Ricketts, 2001). Herbaceous vegetation seems to be the most permeable matrix type for these species. Arboreal mammals can eventually cross matrix to reach other forest fragment and when cross the highway are vulnerable to be hit by vehicles (Sierra et al., 2003). Owls and bats showed the same positive relation to herbaceous vegetation cover than arboreal mammals. Volant mammals and owls can cross highways fast, especially in open vegetation sites with an eventual vehicle collision as consequence. Even forest species of owls can move through matrix, particularly in conditions that promote hunting behavior (Gomes et al., 2009). Despite the low number of road-kill events of reptiles, probably because they are easily detectable with a monitoring on foot (Teixeira et al., 2013), herbaceous vegetation also was positively related to their road-kill. The great distance between the best model and the reference model (M0, intercept) showed by evidence for reptiles, indicates a reliable model to explain reptiles' road-kill. Reptiles use open areas with higher temperatures for thermoregulation and they could find this condition in areas with higher herbaceous vegetation cover, mainly near the highway's surface (Pragatheesh and Rajvanshi, 2013).

Birds do not show a clear relationship between road-kill and landscape characteristics, as indicated by the selection of the reference model (intercept) as the best model to explain birds' road-kill. Birds included almost 40 species with different habitat and matrix perception, some forest species, some occurs in open vegetation areas. We believe that the high diversity and low abundance of each species of road-killed birds may explain how difficult was to find a clear relationship with landscape characteristics for this vertebrate group. In addition, roads and vegetation gaps larger than $30 \mathrm{~m}$ seem to be a barrier for forest birds (Tremblay and St. Clair, 2009); indicating that road-killed birds may be some individuals of each species that randomly crossed the highway. However, a weak relationship was found with less road density and less urban area near highway. Thus, we may consider that road-kill of birds occurred far from cities and in a highway stretch with less curves. Many bird species do not occur in urban areas leading to a low diversity of birds in cities (Chace and Walsh, 2006), indicating that urban matrix is more aggressive and less permeable for birds. Less curved road sections and less steep topography lead to higher speed and higher chance of collision to birds flying at low height crossing the highway (Gunson et al., 2011).

A few large mammals (although smaller than large North American and European mammals) were killed by collision with vehicles, such as Hydrochoerus hydrochaeris, Cerdocyon thous and Chrysocyon brachyurus, and could cause serious accidents, including loss of human lives or substantial material damages for the driver (Huijser et al., 2013). Chrysocyon brachyurus is the only species considered near threatened for the IUCN Red List (IUCN, 2013), and thus is a conservation concern, in addition to be a security issue for drivers. However, most of species killed by vehicles is neither a risk for drivers nor is threatened by extinction. Most of them showed a small amount of road-kill events and, consequently, a low road-kill rate; yet this quantity may represent a relevant impact for these species. This small abundance of road-kill for most species may indicates: 1) the abundance distribution pattern: many rare species and a few common species, showing a hollow curve or hyperbolic shape on a histogram (McGill et al., 2007); 2) species rarely killed by vehicles avoid roads (Jaeger et al., 2005; McGregor et al., 2008; Rosa and Bager, 2013); or, 3) sampling bias for small vertebrates, that is, small vertebrates are less detectable and thus, underestimated in road-kill sample (Teixeira et al., 2013). Neither hypothesis was intended to be tested in this study, but we encourage other researchers to create field experiments to test these hypotheses in tropical ecosystems. Even tough, we considered that the high species diversity hit by vehicles may be considered a conservation issue because could include species with low population or isolated by road due to edge or noise effects (Laurance et al., 2009; McGregor et al., 2008). Particularly in tropics, where land use expansion for food and energy production is a priority for economical development issues, leading to road expansion and improvement of the older roads, especially in Amazon (Fearnside, 2007; Soares-Filho et al., 2004), the conservation concern should be highlighted in the linear infrastructure enterprises.

The association between river proximity and road-kill of all species together indicates that underpasses when rivers cross the highway may be a good mitigation measure. Efficient passages should have large size (wider than long) with vegetation close to the passage entrances (Beckmann et al., 2010; Grilo et al., 2008), and riparian forest strips could act as functional corridor to cross roads depending on matrix permeability particularly to birds (Vergara, 2011). However, there are some restrictions to apply this proposal in the case of Brazilian transportation and environment agencies, and to additional costs to highway manager. Culverts modified to wildlife underpasses were proposed in the report of environmental impact assessment (Petrópolis, 2010); however the Brazilian environment agency did not allow them at that time. The highway manager agreed to install some fences and signs where were many capybaras killed by vehicle collision (Bueno et al., 2013). Fences are cheaper than underpasses, especially because they were installed some hundred of meters near the river blocking capybaras when they tried to cross the road (Huijser et al., 2013). Some preliminary analysis showed that capybaras road-kill events were reduced in this small stretch of the highway. Another mitigation measure suggested in the Environmental Impact Assessment (EIA) report, that is required by Brazilian laws for road duplication or a new road, and agreed by highway manager was speed bumps and radars to prevent wildlife-vehicles collision where there were more human causalities. However, the transport 
agency took some years to allow the installation of speed limit devices. Thus, bureaucracy was the other restriction to implement mitigation measures in our study site, but we believe that this kind of difficulties may occur in other Latin-American countries. Road ecology in Brazil is a novelty in academic studies and there is a great effort to spread the news to government agencies, transportation and environment companies, and the public in general. We believe that there are two main approaches to increase the relevance of road ecology in Brazil and provide the basis for negotiation with government and private companies to get mitigation measures done: security and conservation. Some large animals that may cause more severe accidents with many human causalities and financial damages, such as capybaras, should be used as flagship species for security approach (Bueno et al., 2013; Huijser et al., 2013; Simberloff, 1998). The conservation approach should be used, particularly near protected areas, focusing in biodiversity loss with a community level of analysis, and thus including as many species as possible in mitigation measures. These two approaches could be a way to get attention to decision makers and groups associated to transport and environment.

\section{Conclusion}

We found that matrix was more relevant than habitat to predict road-kill of vertebrates. Two matrix types, river proximity and herbaceous vegetation cover, were associated to road-kill of most of vertebrate groups, indicating these are more permeable matrix types, which have implications on movement behavior of these species and conservation strategies in a community approach. The association between river proximity and road-kill indicates that rivers may be a preferential route for them, and mitigation measures should provide safe passages near rivers. We believe that this association could be found in other regions and the community approach may provide mitigation measures applied to many species at once.

\section{Acknowledgements}

We are thankful to the anonymous reviewers for invaluable comments on this manuscript. We are grateful for support of Concer. Jim Hesson of AcademicEnglishSolutions.com proofread the English.

\section{References}

BALKENHOL, N. and WAITS, L.P., 2009. Molecular road ecology: exploring the potential of genetics for investigating transportation impacts on wildlife. Molecular Ecology, vol. 18, no. 20, pp. 4151-4164. http://dx.doi.org/10.1111/j.1365294X.2009.04322.x. PMid:19732335.

BECKMANN, J.P., CLEVENGER, A.P., HUIJSER, M.P. and HILTY, J.A., 2010. Safe passages: highways, wildlife, and habitat connectivity. Washington: Island Press. 396 p.
BUENO, C., FAUSTINO, M.T. and FREITAS, S.R., 2013. Influence of landscape characteristics on capybara road-kill on highway BR-040, southeastern Brazil. Oecologia Australis, vol. 17, no. 2, pp. 130-137. http://dx.doi.org/10.4257/oeco.2013.1702.11.

BURNHAM, K.P. and ANDERSON, D.R., 2002. Model selection and multi-model inference: a practical information-theoretic approach. New York: Springer. $496 \mathrm{p}$.

CÁCERES, N.C., 2011. Biological characteristics influence mammal road kill in an Atlantic Forest-Cerrado interface in southwestern Brazil. The Italian Journal of Zoology, vol. 78, no. 3, pp. 379-389. http://dx.doi.org/10.1080/11250003.2011.566226.

CHACE, J.F. and WALSH, J.J., 2006. Urban effects on native avifauna: a review. Landscape and Urban Planning, vol. 74, no. 1, pp. 46-69. http://dx.doi.org/10.1016/j.landurbplan.2004.08.007.

CLEVENGER, A.P., CHRUSZCZ, B. and GUNSON, K.E., 2003. Spatial patterns and factors influencing small vertebrate fauna road-kill aggregations. Biological Conservation, vol. 109, no. 1, pp. 15-26. http://dx.doi.org/10.1016/S0006-3207(02)00127-1.

COELHO, C.M., MELO, L.F.B., SÁBATO, M.A.L., MAGNI, E.M.V., HIRSCH, A. and YOUNG, R.J., 2008. Habitat use by wild maned wolves (Chrysocyon brachyurus) in a transition zone environment. Journal of Mammalogy, vol. 89, no. 1, pp. 97-104. http://dx.doi.org/10.1644/06-MAMM-A-383.1.

CORLATTI, L., HACKLÄNDER, K. and FREY-ROOS, F., 2009. Ability of wildlife overpasses to provide connectivity and prevent genetic isolation. Conservation Biology, vol. 23, no. 3, pp. 548-556. http://dx.doi.org/10.1111/j.1523-1739.2008.01162.x. PMid:19210301

DOBROVOLSKI, R., DINIZ-FILHO, J.A.F., LOYOLA, R.D. and MARCO JÚNIOR, P., 2011. Agricultural expansion and the fate of global conservation priorities. Biodiversity and Conservation, vol. 20, no. 11, pp. 2445-2459. http://dx.doi.org/10.1007/s10531011-9997-z.

DORNAS, R.A.P., KINDEL, A., BAGER, A. and FREITAS, S.R., 2012. Avaliação da mortalidade de vertebrados em rodovias no Brasil. In: A. BAGER, ed. Ecologia de estradas: tendências e pesquisas. Lavras: UFLA, pp. 139-152.

FEARNSIDE, P.M., 2007. Brazil's Cuiabá-Santarém (BR-163) highway: the environmental cost of paving a soybean corridor through the Amazon. Environmental Management, vol. 39, no. 5, pp. 601-614. http://dx.doi.org/10.1007/s00267-006-0149-2. PMid:17377730

FORMAN, R.T.T., SPERLING, D., BISSONETTE, J.A., CLEVENGER, A.P., CUTSHALL, C.D., DALE, V.H., FAHRIG, L., FRANCE, R., GOLDMAN, C.R., HEANUE, K., JONES, J.A., SWANSON, F.J., TURRENTINE, T. and WINTER, T.C., 2003. Road ecology: science and solutions. Washington: Island Press. 481 p.

FREITAS, S.R., HAWBAKER, T.J. and METZGER, J.P., 2010. Effects of roads, topography, and land use on forest cover dynamics in the Brazilian Atlantic Forest. Forest Ecology and Management, vol. 259, no. 3, pp. 410-417. http://dx.doi. org/10.1016/j.foreco.2009.10.036.

GARRIGA, N., SANTOS, X., MONTORI, A., RICHTER-BOIX, A., FRANCH, M. and LLORENTE, G.A., 2012. Are protected areas truly protected? The impact of road traffic on vertebrate fauna. Biodiversity and Conservation, vol. 21, no. 11, pp. 27612774. http://dx.doi.org/10.1007/s10531-012-0332-0. 
GOMES, L., GRILO, C., SILVA, C. and MIRA, A., 2009. Identification methods and deterministic factors of owl roadkill hotspot locations in Mediterranean landscapes. Ecological Research, vol. 24, no. 2, pp. 355-370. http://dx.doi.org/10.1007/ s11284-008-0515-z.

GRILO, C., BISSONETTE, J.A. and SANTOS-REIS, M., 2008. Response of carnivores to existing highway culverts and underpasses: implications for road planning and mitigation. Biodiversity and Conservation, vol. 17, no. 7, pp. 1685-1699. http://dx.doi.org/10.1007/s10531-008-9374-8.

GUNSON, K.E., MOUNTRAKIS, G. and QUACKENBUSH, L.J., 2011. Spatial wildlife-vehicle collision models: a review of current work and its application to transportation mitigation projects. Journal of Environmental Management, vol. 92, no. 4, pp. 1074-1082. http://dx.doi.org/10.1016/j.jenvman.2010.11.027. PMid:21190788.

HUIJSER, M.P., ABRA, F.D. and DUFFIELD, J.W., 2013. Mammal road mortality and cost-benefit analyses of mitigation measures aimed at reducing collisions with capybara (Hydrochoerus hydrochaeris) in São Paulo state, Brazil. Oecologia Australis, vol. 17, no. 1, pp. 129-146. http://dx.doi.org/10.4257/oeco.2013.1701.11.

HUIJSER, M.P., DUFFIELD, J.W., CLEVENGER, A.P., AMENT, R.J. and MCGOWEN, P.T., 2009. Cost-benefit analyses of mitigation measures aimed at reducing collisions with large ungulates in the Unites States and Canada: a decision support tool. Ecology and Society, vol. 14, no. 2, pp. 15.

INSTITUTO DE ESTUDOS SOCIOAMBIENTAIS DO SUL DA BAHIA - IESB, 2007. Levantamento da cobertura vegetal nativa do bioma Mata Atlântica. Brasília: PROBIO/MMA. 84 p.

INTERNATIONAL UNION FOR CONSERVATION OF NATURE - IUCN, 2013 [viewed 16 October 2013]. IUCN Red List of Threatened Species. Version 2013.1 [online]. Cambridge. Available from: www.iucnredlist.org

JAEGER, J.A.G., BOWMAN, J., BRENNAN, J., FAHRIG, L., BERT, D., BOUCHARD, J., CHARBONNEAU, N., FRANK, K., GRUBER, B. and VON TOSCHANOWITZ, K.T., 2005. Predicting when animal populations are at risk from roads: an interactive model of road avoidance behavior. Ecological Modelling, vol. 185, no. 2-4, pp. 329-348. http://dx.doi.org/10.1016/j. ecolmodel.2004.12.015.

LAURANCE, W.F., GOOSEM, M. and LAURANCE, S.G.W., 2009. Impacts of roads and linear clearings on tropical forests. Trends in Ecology \& Evolution, vol. 24, no. 12, pp. 659-669. http://dx.doi.org/10.1016/j.tree.2009.06.009. PMid:19748151.

LESBARRÈRES, D. and FAHRIG, L., 2012. Measures to reduce population fragmentation by roads: what has worked and how do we know? Trends in Ecology \& Evolution, vol. 27, no. 7, pp. 374380. http://dx.doi.org/10.1016/j.tree.2012.01.015. PMid:22356922.

LESBARRÈRES, D., PRIMMER, C.R., LODÉ, T. and MERILÄ, J., 2006. The effects of 20 years of highway presence on the genetic structure of Rana dalmatina populations. Ecoscience, vol. 13, no. 4, pp. 531-538. http://dx.doi.org/10.2980/11956860(2006)13[531:TEOYOH]2.0.CO;2.

LIMA NETO, O.L., 2001. Transportes no Brasil: história e reflexões. Brasília: Empresa Brasileira de Planejamento de Transportes/GEIPOT. 525 p.

LINNAEUS, C., 1766. Systema naturae per regna tria naturae, secundum classes, ordines, genera, species, cum characteribus, differentiis, synonymis, locis. 10th ed. Holmiae: Laurentii Salvii. $532 \mathrm{p}$. Tomus I.

MCGILL, B.J., ETIENNE, R.S., GRAY, J.S., ALONSO, D., ANDERSON, M.J., BENECHA, H.K., DORNELAS, M., ENQUIST, B.J., GREEN, J.L., HE, F., HURLBERT, A.H., MAGURRAN, A.E., MARQUET, P.A., MAURER, B.A., OSTLING, A., SOYKAN, C.U., UGLAND, K.I. and WHITE, E.P., 2007. Species abundance distributions: moving beyond single prediction theories to integration within an ecological framework. Ecology Letters, vol. 10, no. 10, pp. 995-1015. http:// dx.doi.org/10.1111/j.1461-0248.2007.01094.x. PMid:17845298.

MCGREGOR, R.L., BENDER, D.J. and FAHRIG, L., 2008. Do small mammals avoid roads because of the traffic? Journal of Applied Ecology, vol. 45, no. 1, pp. 117-123. http://dx.doi. org/10.1111/j.1365-2664.2007.01403.x.

PETRÓPOLIS. Céu Aberto. Concer, 2010 [viewed 24 May 2012]. Estudo de impacto ambiental da nova subida da Serra de Petrópolis - RJ BR-040 [online]. Petrópolis: Câmara Municipal de Petrópolis. Available from: http://www.cmp.rj.gov.br/planodiretor/pdf/EIA\%20 -\%20RIMA/RIMA/EIA_CONCER_RIMA_REV31corrigido.pdf

PRAGATHEESH, A. and RAJVANSHI, A., 2013. Spatial patterns and factors influencing the mortality of snakes on the national highway-7 along Pench Tiger Reserve, Madhya Pradesh, India. Oecologia Australis, vol. 17, no. 1, pp. 20-35. http://dx.doi. org/10.4257/oeco.2013.1701.03.

PREVEDELLO, J.A. and VIEIRA, M.V., 2010. Does the type of matrix matter? A quantitative review of the evidence. Biodiversity and Conservation, vol. 19, no. 5, pp. 1205-1223. http://dx.doi. org/10.1007/s10531-009-9750-z.

REIS, N.R., PERACCHI, A.L., FREGONEZI, M.N. and ROSSANEIS, B.K., 2010. Mamíferos do Brasil: guia de identificação. Rio de Janeiro: Technical Books. 560 p.

RICKETTS, T.H., 2001. The matrix matters: effective isolation in fragmented landscapes. American Naturalist, vol. 158, no. 1, pp. 87-99. http://dx.doi.org/10.1086/320863. PMid:18707317.

ROSA, C.A. and BAGER, A., 2013. Review of the factors underlying the mechanisms and effects of roads on vertebrates. Oecologia Australis, vol. 17, no. 1, pp. 6-19. http://dx.doi. org/10.4257/oeco.2013.1701.02.

ROSKOV, Y., KUNZE, T., PAGLINAWAN, L., ORRELL, T., NICOLSON, D., CULHAM, A., BAILLY, N., KIRK, P., BOURGOIN, T., BAILLARGEON, G., HERNANDEZ, F. and DE WEVER, A., 2013 [viewed 6 March 2014]. Species 2000 \& ITIS Catalogue of Life [online]. Leiden: Naturalis Biodiversity Center. Available from: www.catalogueoflife.org/col/

SCHUSTER, R., RÖMER, H. and GERMAIN, R.R., 2013. Using multi-scale distribution and movement effects along a montane highway to identify optimal crossing locations for a large-bodied mammal community. PeerJ, vol. 1, pp. e189. http:// dx.doi.org/10.7717/peerj.189. PMid:24244912.

SEILER, A., 2005. Predicting locations of moose-vehicle collisions in Sweden. Journal of Animal Ecology, vol. 42, no. 2, pp. 371-382. http://dx.doi.org/10.1111/j.1365-2664.2005.01013.x.

SHEPARD, E.L.C., WILSON, R.P., REES, W.G., GRUNDY, E., LAMBERTUCCI, S.A. and VOSPER, S.B., 2013. Energy landscapes shape animal movement ecology. American Naturalist, vol. 182, no. 3, pp. 298-312. http://dx.doi.org/10.1086/671257. PMid:23933722. 
SIERRA, C., JIMÉNEZ, I., ALTRICHTER, M., FERNÁNDEZ, M., GÓMEZ, G., GONZÁLEZ, J., HERNÁNDEZ, C., HERRERA, H., JIMÉNEZ, B., LÓPEZ-ARÉVALO, H., MILLÁN, J., MORA, G. and TABILO, E., 2003. New data on the distribution and abundance of Saimiri oerstedii citrinellus. Primate Conservation, vol. 19, pp. 5-9.

SIMBERLOFF, D., 1998. Flagships, umbrellas, and keystones: is single-species management passé in the landscape era? Biological Conservation, vol. 83, no. 3, pp. 247-257. http://dx.doi.org/10.1016/ S0006-3207(97)00081-5.

SOARES-FILHO, B., ALENCAR, A., NEPSTAD, D., CERQUEIRA, G., DIAZ, M.C.V., RIVERO, S., SOLÓRZANO, L. and VOLL, E., 2004. Simulating the response of land-cover changes to road paving and governance along a major Amazon highway: the Santarém-Cuiabá corridor. Global Change Biology, vol. 10, no. 5, pp. 745-764. http://dx.doi.org/10.1111/j.1529-8817.2003.00769.x.

TAYLOR, P.D., FAHRIG, L., HENEIN, K. and MERRIAM, G., 1993. Connectivity is a vital element of landscape structure. Oikos, vol. 68, no. 3, pp. 571-573. http://dx.doi.org/10.2307/3544927.

TEIXEIRA, F.Z., COELHO, A.V.P., ESPERANDIO, I.B. and KINDEL, A., 2013. Vertebrate road mortality estimates: effects of sampling methods and carcass removal. Biological Conservation, vol. 157, pp. 317-323. http://dx.doi.org/10.1016/j. biocon.2012.09.006.
TREMBLAY, M.A. and ST. CLAIR, C.C., 2009. Factors affecting the permeability of transportation and riparian corridors to the movements of songbirds in an urban landscape. Journal of Applied Ecology, vol. 46, no. 6, pp. 1314-1322.

VAN DER REE, R., JAEGER, J.A.G., VAN DER GRIFT, E.A. and CLEVENGER, A.P., 2011. Effects of roads and traffic on wildlife populations and landscape function: Road Ecology is moving toward larger scales. Ecology and Society, vol. 16, no. 1, pp. 48.

VERDADE, L.M. and FERRAZ, K.M.P.M.B., 2006. Capybaras in an anthropogenic habitat in southeastern Brazil. Brazilian Journal of Biology $=$ Revista Brasileira de Biologia, vol. 66, no. 1B, pp. 371-378. http://dx.doi.org/10.1590/S1519-69842006000200019. PMid:16710529.

VERGARA, P.M., 2011. Matrix-dependent corridor effectiveness and the abundance of forest birds in fragmented landscapes. Landscape Ecology, vol. 26, no. 8, pp. 1085-1096. http://dx.doi. org/10.1007/s10980-011-9641-z.

ZELLER, K.A., MCGARIGAL, K. and WHITELEY, A.R., 2012. Estimating landscape resistance to movement: a review. Landscape Ecology, vol. 27, no. 6, pp. 777-797. http://dx.doi. org/10.1007/s10980-012-9737-0. 